\title{
Growth and Yields of Bell Pepper and Winter Squash Grown with Organic and Living Mulches
}

\author{
Nancy E. Roe ${ }^{1}$ and Peter J. Stoffella ${ }^{2}$ \\ Agricultural Research and Education Center, Institute of Food and Agricultural Sciences, University of \\ Florida, 2199 South Rock Road, Fort Pierce, FL 34945 \\ Herbert H. Bryan ${ }^{2}$ \\ Tropical Research and Education Center, Institute of Food and Agricultural Sciences, University of \\ Florida, 18905 Southwest 280th Street, Homestead, FL 33031
}

\begin{abstract}
Additional index words. compost, sewage sludge, municipal solid waste, wood chips, Capsicum annuum, Cucurbita pepo, Arachis glabrata, Stenotaphrum secundatum
\end{abstract}

\begin{abstract}
Increasing disposal problems with polyethylene (PL) mulch and greater availability of compost prompted an investigation into the effects of using compost as a mulch on horizontal raised bed surfaces with living mulches (LMs) on vertical surfaces. Wood chips (WC), sewage sludge-yard trimming (SY) compost, and municipal solid waste (MW) compost were applied at $224 \mathrm{t} \cdot \mathrm{ha}^{-1}$ on bed surfaces. Sod strips of 'Jade' (JD) or 'Floratam' (FT) St. Augustinegrass (Stenotaphrum secundatum Kuntze) or perennial peanut (Arachis glabrata Benth.) (PP) or seeds of a small, seedpropagated forage peanut (Arachis sp.) (SP) were established on the vertical sides of the raised beds before transplanting bell pepper (Capsicum annuum $\mathrm{L}$.) into the beds. Phytophthora capsici reduced pepper plant stand in PL-mulched plots compared with organic mulch $(O M)$ and $L M$. Despite the stand reduction, total pepper yields were highest in PL plots and, in the OM plots, decreased in the order SY > MW > WC. Early fruit yields and yield per plant were highest from plants in PL plots followed by SY. Among LMs, plants in SP plots produced highest early yields and FT produced the lowest. Plants in PL plots produced the largest fruit. When the same plots were seeded with winter (butternut) squash (Cucurbita pepo L.), plant stands were higher in MW than WC and SY. Squash yields were similar between PL and OM plots.
\end{abstract}

Mulches can reduce water evaporation from the soil's surface, suppress weed growth, restrict fertilizer leaching, and moderate diurnal and seasonal temperature fluctuations.

About 9.5 million $\mathrm{kg}$ of polyethylene (PL) mulch is used in Florida annually (Servis, 1992). Although PL mulch has dramatically increased the yields of some vegetable crops, mulch disposal is costly to growers and society. In some areas of Florida, disposal costs increased by as much as $30 \%$ in 1 year (Servis, 1992).

Florida's Solid Waste Act of 1988 mandated a 30\% reduction in landfilling by Dec. 1994 and prohibited disposal of yard trimmings in landfills after 1 Jan. 1992, resulting in substantial quantities of organic matter available for commercial agricultural uses.

In southern Florida, bell peppers are commonly grown on raised beds due to heavy rainfall during the growing season. When organic mulches (OMs) rather than PL mulches are used, the vertical sides of the beds may deteriorate. Living mulches (LMs) can alleviate soil erosion and maintain soil structure (Grubinger and Minotti, 1990) and may potentially reduce bed degradation.

The objective of these experiments was to determine the influence of several LMs combined with OMs on growth, nutrient status, and yields of bell pepper and winter squash.

\section{Materials and Methods}

Two experiments were conducted on a commercial bell pepper field in Boynton Beach, Fla. Soil type was a Myakka sand (sandy,

Received for publication 19 Oct. 1993. Accepted for publication 22 Mar. 1994. Univ. of Florida Agr. Expt. Sta. Journal series no. R-03431. We acknowledge the support of Mr. and Mrs. Ted Winsberg of Green Cay Farms. The cost of publishing this paper was defrayed in part by the payment of page charges. Under postal regulations, this paper therefore must be hereby marked advertisement solely to indicate this fact.

${ }^{1}$ Postdoctoral research associate. Current address: Texas A \& M Univ. Research and Extension Center, Rt. 2, Box 1, Stephensville, TX 76401.

${ }^{2}$ Professor. siliceous, hyperthermic Aeric Haplaquad). Beds were constructed 20 $\mathrm{cm}$ high, $92 \mathrm{~cm}$ wide, and were spaced $1.7 \mathrm{~m}$, center to center.

Soil electrical conductivity (EC), $\mathrm{NO}_{3}-\mathrm{N}$, and $\mathrm{pH}$ were extracted in a 2 water : 1 soil (v/v) suspension. The Walkley-Black dichromate method was used to determine percent organic matter (Nelson and Sommers, 1982). Phosphorus, K, Ca, Mg, Mn, Zn, and $\mathrm{Cu}$ were extracted by the Mehlich I method and analyzed by inductively coupled argon plasma (ICP) spectroscopy (Hanlon et al., 1990).

Extractions for municipal solid waste (MW) compost were performed with a Morgan solution (Wolfe, 1982). Nitrogen, P, and $\mathrm{S}$ were determined spectrophotometrically. Calcium, $\mathrm{K}, \mathrm{Mg}, \mathrm{Zn}$, $\mathrm{Mn}, \mathrm{Cu}$, and $\mathrm{Fe}$ were determined by atomic absorption. EC and $\mathrm{pH}$ were measured in a 2 water : 1 soil suspension.

Total $\mathrm{N}$ in sewage sludge-yard trimming (SY) compost was analyzed using an $\mathrm{N}$ analyzer. Phosphorus, $\mathrm{K}, \mathrm{Ca}, \mathrm{Mg}, \mathrm{Mn}, \mathrm{Zn}, \mathrm{Cu}$, $\mathrm{Fe}$, and $\mathrm{S}$ were analyzed by ICP spectroscopy.

An analysis of variance (ANOVA) was conducted by SAS for each measured variable. Orthogonal contrasts were performed using PL vs. all other treatments. Another ANOVA (with PL treatments removed) was performed with LM and OM as main effects. Since most $\mathrm{LM} \times \mathrm{OM}$ interactions were nonsignificant, means separation of the main effects of LM and OM were performed by Duncan's multiple range test at $P \leq 0.05$.

Bell pepper experiment. On 15 Jan. 1992, a previous bell pepper crop was removed by mowing. Beds, size and shape as previously described, were not replaced. Main plots were $9.1 \mathrm{~m}$ long and consisted of three beds and bed sides. A factorial treatment combination of four LMs and three OMs, and a control (PL mulch) was used. Subplots were $9.1 \mathrm{~m}$ long and consisted of one bed and bed sides. A split-plot experimental design, with LMs as main plots and OMs as subplots, replicated five times was used.

The white PL mulch (0.0318 mm thick) used for the preceding crop was left on the plots and designated as the control. On 24 Jan. 1992, PL was removed from the plots where the LMs were to be 
Table 1. Chemical characteristics of municipal solid waste (MW) and sewage sludge-yard trimming (SY) composts.

\begin{tabular}{|c|c|c|c|c|c|c|c|c|c|c|c|c|c|}
\hline \multirow[b]{2}{*}{ Mulch } & \multirow[b]{2}{*}{$\mathrm{pH}$} & \multirow[b]{2}{*}{$\mathrm{SS}^{\mathrm{z}}$} & \multicolumn{11}{|c|}{ Concn $\left(\mathrm{mg} \cdot \mathrm{kg}^{-1}\right)$} \\
\hline & & & $\mathrm{N}$ & $\mathrm{P}$ & $\mathrm{K}$ & $\mathrm{Ca}$ & $\mathrm{Mg}$ & $\mathrm{Fe}$ & $\mathrm{Mn}$ & $S$ & $\mathrm{Zn}$ & $\mathrm{Cu}$ & B \\
\hline$\overline{\mathrm{MW}^{\mathrm{y}}}$ & 8.2 & 2.50 & 7 & 47 & 532 & 2210 & 164 & 8 & 16 & 378 & 17 & 0.3 & 7.0 \\
\hline$S Y^{x}$ & 7.2 & NA & 13,000 & 9940 & 2400 & 2500 & 37,500 & 11,400 & 200 & 5900 & 300 & 500.0 & 20.0 \\
\hline
\end{tabular}

${ }^{\mathrm{z}} \mathrm{SS}=$ soluble salts $\left(\mathrm{mmhos} \cdot \mathrm{cm}^{-1}\right)$.

yAnalysis obtained from Reuter Recycling.

${ }^{\mathrm{x}}$ Analysis obtained from Palm Beach County Solid Waste Authority.

established. The St. Augustine grasses 'Floratam' (FT) and 'Jade' (JD), in $40 \times 60-\mathrm{cm}$ sod pieces, were creased in the center and laid on bed sides with about half of the strip lying vertically along the bed and half lying horizontally in the alley.

Sodium $N$-methyldithiocarbamate (Vapam) at 74 liter $\cdot \mathrm{ha}^{-1}$ was injected into all beds on $29 \mathrm{Jan}$. using an injection wheel with openings at $30 \mathrm{~cm}$.

Perennial peanut (PP) rhizome mats were laid on 7 Feb. in the same manner as the grass sod. There was minimal soil around the peanut roots; therefore, they were covered slightly by removing soil from the bed surfaces and alleys.

To protect bed surfaces during the LM growth period, aged wood chips (WC), principally from Melaleuca quinquenervia (Cav.) Blake, were spread $5 \mathrm{~cm}$ deep on bed surfaces on $21 \mathrm{Feb}$.

A small-seeded forage peanut (Arachis sp.) (SP) was seeded into bed sides on $28 \mathrm{Feb}$. Each hill, consisting of two to three seeds, was planted $2.5 \mathrm{~cm}$ deep and $20 \mathrm{~cm}$ apart. Percent germination was $62 \%$ by a 5 -day germination test in moist paper towels at room temperature. Hills lacking an emerged seedling were reseeded with three to four seeds on 13 Mar.

LMs were weeded as needed and watered by subsurface seepage irrigation during spring and summer. Growth of one-half of each FT plot was mowed on 27 Mar., 17 Apr., 22 June, and 29 July 1992 and 22 Jan. 1993. The other half was sprayed with butyl 2-[4(5-trifluoromethyl-2-pyridinyloxy) phenoxy] propanoate (fluazifop) at $0.16 \mathrm{~kg} \cdot \mathrm{ha}^{-1}$ (Hinton and Minotti, 1983) on 4 May and 25 Aug. 1992 and 8 Jan. 1993 using a manually operated backpack pump sprayer. JD plots were treated similarly, but slower growth necessitated mowing only on 22 June 1992 and 22 Jan. 1993 and applying herbicide only on 25 Aug. 1992

WC compost was removed from surfaces of two of the three beds in each (main) LM plot on 6 June. On 17 June, MW compost (Reuter Recycling of Florida, Pembroke Pines, Fla.) (Table 1) was spread manually on one of these uncovered beds in each LM plot. On 8 July, the remaining bed in each main plot was covered with SY compost made in a covered-bin facility operated by Palm Beach County, Fla. Both mulches were used at a rate of 224 t.ha ${ }^{-1}$, resulting in a depth of $\approx 5 \mathrm{~cm}$.

Drip irrigation was installed on 31 Aug. One drip line (Netafim, Orlando, Fla.) was laid 2 to $5 \mathrm{~cm}$ deep in the center of each bed. Emitters spaced at $45 \mathrm{~cm}$ each delivered $\approx 18 \mathrm{ml} \cdot \mathrm{min}^{-1}$. Two daily irrigations were used, with each supplying $\approx 9340$ liter $\cdot \mathrm{ha}^{-1}$. Nutrients at $1.1 \mathrm{~N}-0.9 \mathrm{~K}\left(\mathrm{~kg} \cdot \mathrm{ha}^{-1}\right)$ were added through the irrigation system with each application to all plots. White PL mulch $(0.0318$ $\mathrm{mm}$ thick) was replaced in PL plots, but no additional mulch was added to OM plots. On 17 Sept., isopropylamine salt of $N$ (phosphonomethyl) glycine (glyphosate) spray was applied to the bed surfaces at a rate of 3 liter $\cdot \mathrm{ha}^{-1}$ to control weeds and LMs that had grown onto the surface.

Soil samples were taken 0.0 to 7.5 and 7.5 to $15.0 \mathrm{~cm}$ deep on 23 Sept. using a 5 -cm-diameter sampling tube. Samples were airdried for 60 days before testing for $\mathrm{NH}_{4}-\mathrm{N}, \mathrm{NO}_{3}-\mathrm{N}, \mathrm{P}, \mathrm{K}, \mathrm{Ca}, \mathrm{Mg}$, $\mathrm{Zn}, \mathrm{Cu}, \mathrm{Mn}$, and organic matter. Data from these soil tests were analyzed as a split-split plot experimental design using LM as the main plot, OM as the subplot, and soil depth as the sub-subplot.

Bell pepper seedlings ('PR-3002'), $\approx 5$ weeks-old, were transplanted into the beds on 6 Oct. Plants were spaced $30 \mathrm{~cm}$ apart in two rows spaced $45 \mathrm{~cm}$ apart. Plant population was 39,120 plants/ha.

The most recently matured leaf from 15 plants in each plot was collected for tissue analysis on 4 Dec. 1992. Leaves were dried for 5 days at $68 \mathrm{C}$, ground, extracted, and analyzed according to Hanlon and DeVore (1989).

One plant from each plot was severed at the soil's surface on 4 Dec. 1992. Two root core samples were taken from each of these plants, $5 \mathrm{~cm}$ from the plant toward the outside edge of the bed, and $5 \mathrm{~cm}$ from the plant toward the center of the bed. Samples were taken from the mulch and from soil depths of 0.0 to 7.5 and 7.5 to $15 \mathrm{~cm}$ using the same sampling tube used to extract soil samples. Roots were washed and screened to separate them from the mulch or soil (Jackson and Bloom, 1990). Shoots (including attached fruit) and roots were dried at 70C for 11 days and weighed. Percentages of roots at each soil depth were transformed using a square-root arcsin before conducting an ANOVA.

Fruit were harvested on 29 Dec. 1992 and 18 Jan. 1993 from a 6.1-m length of each plot. Due to plant losses to Phytophthora, mowed and herbicide-treated subplots of the grass LM plots were combined for harvest data collection. In the first harvest, fruit were graded into large (U.S. Fancy, diameter at least $7.5 \mathrm{~cm}$ and length at least $8.75 \mathrm{~cm}$ ) and medium (U.S. no. 1, diameter and length at least $6.75 \mathrm{~cm}$ ) (Hochmuth, 1988). In the second harvest, all marketable graded fruit were U.S. medium.

Winter squash experiment. The pepper plants were removed by mowing on 22 Jan. 1993. This process also resulted in mowing much of the 'Floratam' St. Augustinegrass, since it reached $0.5 \mathrm{~m}$ above the bed surface in some plots. Bed surfaces were sprayed with glyphosate (3 liter $\cdot \mathrm{ha}^{-1}$ ) to kill weeds and remaining pepper plants. The MW and SY mulches were about half their original depth.

'Waltham' butternut squash was manually seeded on $4 \mathrm{Feb}$. into machine-made holes spaced $23 \mathrm{~cm}$ apart and slightly offset from the center of each bed, with one seed per hole. Plots were manually weeded on 19 Feb., 9 Mar., and 24 Mar. Plants in each plot were counted on 1 Mar. and reported as the percentage of the potential plants per plot.

Soil temperatures were recorded three times daily using a temperature probe inserted $15 \mathrm{~cm}$ deep in one random location per plot on 10, 11, 12, 14, 15, 16, 28, and 30 Mar. Temperatures were designated as morning (between 7:00 and 8:00 AM), midday (between 1:00 and 2:00 PM), or evening (between 5:00 and 6:00 PM).

Fruit longer than $15 \mathrm{~cm}$ were harvested, weighed, and counted on 11 May, and data were analyzed as previously described.

\section{Results and Discussion}

\section{Bell pepper experiment}

Soil tests. $\mathrm{LM} \times \mathrm{OM} \times$ soil depth (D) and $\mathrm{LM} \times \mathrm{OM}$ interactions were not significant for any measured variable (Table 2). 
The $\mathrm{OM} \times \mathrm{D}$ interaction was significant for soil $\mathrm{P}, \mathrm{K}$, and $\mathrm{Mg}$ concentrations. Soil $\mathrm{P}$ concentration was higher in deeper soil under WC compost and lower under SY and MW composts than at the shallow depth. Potassium and $\mathrm{Mg}$ concentrations were higher in deeper soil under MW and lower under WC and SY than at the shallow depth. Additional $\mathrm{K}$ and Mg provided by the SY mulch (Table 1) and the susceptibility of $\mathrm{K}$ and $\mathrm{Mg}$ to leaching may have resulted in higher concentrations of these elements at the shallow depth.

The $\mathrm{LM} \times \mathrm{D}$ interaction was significant for soil Ca concentration. Calcium concentration was higher at the deeper depth in PP plots and lower at deeper depth in the other LMs. This may be related to the differential in Ca uptake and use between the PP and the other LMs.

Soil $\mathrm{NO}_{3}$ concentration was higher in PL plots compared with OM plots and in SY plots compared with the other two OMs (Table 2). Paul and Clark (1989) reported that lack of tillage tends to increase microbial activity at or near the soil's surface. Nitrate produced by nitrification of the organic $\mathrm{N}$ in the compost may have leached equally into both soil depths, with most lost through deeper soil leaching. Fertilizer was not applied to PL plots for 1 year before soil sampling. However, despite adding compost to OM plots, soil $\mathrm{N}$ and a large portion of $\mathrm{K}$ and $\mathrm{Mg}$ remained higher in PL plots, apparently due to the prevention of leaching by PL mulch. The other plots were unmulched for 1 month, mulched with wood chips for 3 to 4 months, and mulched with OM compost for 3 additional months before the soil samples were taken. Soil pH was 7.2, and, with the high $\mathrm{pH}$ of the composts (Table 1) and the high moisture level maintained by seepage irrigation, additional $\mathrm{N}$ may have been lost through volatilization.

Soil P concentration under PL mulch was similar to that of OM plots (Table 2). Tukey and Schoff (1963) measured higher soil P concentration under legume hay and straw mulches but not under peanut hulls, corn cobs, sawdust, or foam rubber compared with grass sod or cultivated plots.

PL-mulched plots were higher in soil K compared with other treatments (Table 2). Tukey and Schoff (1963) reported greater availability of weakly and readily available $\mathrm{K}$ in soils under legume hay than under synthetic mulches. They also reported no consistent or significant differences in $\mathrm{Ca}$ or $\mathrm{Mg}$ concentration between soils incubated under one of five different OMs or four synthetic mulches. Soil Ca concentration in our plots was higher in SY and MW compost plots than in WC compost plots. PL-mulched plots had higher soil $\mathrm{Mg}$ concentration compared with other treatments (Table 2). Higher soil Mg concentration in PP and SP suggests that the more vigorous FT may have used more of the available $\mathrm{Mg}$.

Soil organic matter content was higher in plots with JD, PP, and SP LMs than in those with FT. The FT was the most vigorous LM, a result suggesting higher organic matter production. However, the organic matter content in FT plots at this sampling date may have been in large portions that were screened out before testing.

OMs did not seem to reduce nutrient leaching as much as PL mulch. A mature compost incorporated into the soil may have retained more nutrients than the mulches. Duxbury et al. (1989) alluded to insufficient information on which pools of organic matter (old, stable or newer, labile) most influence cation exchange capacity (CEC). However, CEC of humic acid increases with increasing $\mathrm{pH}$ (Harada et al., 1975), and humic acid increases with compost maturity (Jimenez and Garcia, 1992). Soil testing methods used here may not have extracted all nutrients from the organic fraction of the soil, as testing methods that may be accurate on unamended soils may not be appropriate for the same soils with organic matter amendments (O'Keefe et al., 1986).

Leaf tissue samples. Nutrients in all leaf tissue samples tested were in the adequate or high range for early fruit setting of peppers (Hochmuth et al., 1991).

Table 2. Soil characteristics of experimental plots before transplanting peppers.

\begin{tabular}{|c|c|c|c|c|c|c|c|c|c|}
\hline \multirow[b]{2}{*}{ Mulch $^{2}$} & \multicolumn{8}{|c|}{ Concn $\left(\mathrm{mg} \cdot \mathrm{kg}^{-1}\right)$} & \multirow{2}{*}{$\begin{array}{c}\text { Organic } \\
\text { matter }(\%)\end{array}$} \\
\hline & $\mathrm{NO}_{3}$ & $\mathrm{P}$ & $\mathrm{K}$ & $\mathrm{Ca}$ & $\mathrm{Mg}$ & $\mathrm{Zn}$ & $\mathrm{Cu}$ & $\mathrm{Mn}$ & \\
\hline PL & 15.6 & 279 & 74.0 & 1797 & 105.1 & 14.0 & 12.9 & 23.6 & 1.4 \\
\hline \multicolumn{10}{|c|}{ Living mulch (LM) } \\
\hline FT & 1.5 & 264 & 42.1 & 1478 & $75.8 \mathrm{~b}^{\mathrm{y}}$ & 14.6 & 10.7 & 17.3 & $1.3 \mathrm{~b}$ \\
\hline JD & 2.1 & 281 & 44.6 & 1885 & $80.5 \mathrm{ab}$ & 14.9 & 10.0 & 18.0 & $1.5 \mathrm{a}$ \\
\hline PP & 0.3 & 277 & 46.3 & 1778 & $91.9 \mathrm{a}$ & 15.1 & 11.0 & 18.4 & $1.6 \mathrm{a}$ \\
\hline $\mathrm{SP}$ & 1.3 & 274 & 45.7 & 1572 & $91.9 \mathrm{a}$ & 18.6 & 10.6 & 17.5 & $1.5 \mathrm{a}$ \\
\hline \multicolumn{10}{|c|}{ Organic mulch (OM) } \\
\hline MW & $0.6 \mathrm{~b}$ & $263 \mathrm{~b}$ & $23.7 \mathrm{~b}$ & $1791 \mathrm{a}$ & 82.2 & 15.6 & $9.9 \mathrm{~b}$ & 17.8 & 1.5 \\
\hline WC & $0.1 \mathrm{~b}$ & $271 \mathrm{~b}$ & $17.3 \mathrm{c}$ & $1556 \mathrm{~b}$ & 86.8 & 14.2 & $11.6 \mathrm{a}$ & 17.3 & 1.5 \\
\hline SY & $3.1 \mathrm{a}$ & $288 \mathrm{a}$ & $93.1 \mathrm{a}$ & $1688 \mathrm{a}$ & 86.1 & 17.6 & $10.2 \mathrm{~b}$ & 18.2 & 1.5 \\
\hline \multicolumn{10}{|c|}{ Soil depth (D) (cm) } \\
\hline $0.0-7.5$ & 1.0 & 275 & 15.7 & 1696 & 86.2 & 15.7 & 10.7 & 17.5 & 1.5 \\
\hline $7.5-15.0$ & 1.6 & 273 & 41.7 & 1661 & 83.8 & 15.9 & 10.5 & 18.0 & 1.5 \\
\hline $\mathrm{F}$ test $(\mathrm{D})$ & NS & NS & $* *$ & NS & NS & NS & NS & NS & NS \\
\hline \multicolumn{10}{|l|}{ Interactions } \\
\hline $\mathrm{LM} \times \mathrm{OM}$ & NS & NS & NS & NS & NS & NS & NS & NS & NS \\
\hline $\mathrm{OM} \times \mathrm{D}$ & NS & $* *$ & $* *$ & NS & $* *$ & NS & NS & NS & NS \\
\hline $\mathrm{LM} \times \mathrm{D}$ & NS & NS & NS & $* *$ & NS & NS & NS & NS & NS \\
\hline $\mathrm{LM} \times \mathrm{OM} \times \mathrm{D}$ & NS & NS & NS & NS & NS & NS & NS & NS & NS \\
\hline \multicolumn{10}{|l|}{ Contrasts } \\
\hline PL vs. others & $* *$ & NS & $* *$ & $* *$ & $* *$ & NS & $* *$ & $* *$ & NS \\
\hline
\end{tabular}

${ }^{\mathrm{z}} \mathrm{PL}=$ polyethylene, $\mathrm{FT}=$ 'Floratam', JD = 'Jade', $\mathrm{PP}=$ perennial peanut, $\mathrm{SP}=$ seed-propagated forage peanut, $\mathrm{MW}=$ municipal solid waste compost, $\mathrm{WC}=$ wood chips, $\mathrm{SY}=$ sewage sludge-yard trimming compost.

yMean separation in columns within mulch types by Duncan's multiple range test, $P=0.05$.

Ns, ${ }^{* *}$ Nonsignificant or significant at $P=0.01$. 
The $\mathrm{OM} \times \mathrm{LM}$ interaction was significant for leaf $\mathrm{K}$ concentrations (Table 3), which was highest in plants grown in SY with all LMs except FT, in which K was highest in plants from WC plots. Higher leaf $\mathrm{K}$ concentration in SY plots may be a result of higher soil K concentration in SY plots (Table 2). Leaf K concentration was lowest in MW with all LMs. Miller (1960) reported highest K in plants that received high $\mathrm{K}$ or low $\mathrm{P}$ or $\mathrm{Mg}$ fertilizer solutions, indicating that interactions of these ions affect their availability.

The $\mathrm{OM} \times \mathrm{LM}$ interaction was also significant for leaf $\mathrm{Mg}$ concentration (Table 3), which was highest in SY OM with all LMs except SP, in which Mg was highest with WC. Leaf Mg was lowest in MW OM with FT LM, in WC OM with JD and PP LMs, and in SY OM with SP LM.

Thomas and Heilman (1964) reported that pepper yields were positively correlated to leaf $\mathrm{N}$ content and fertilizer $\mathrm{N}$ added. Leaf $\mathrm{N}$ content from plants grown with grassy LMs was generally higher than in plants from plots with peanut mulches (Table 3), but yields were not higher than in peanut LMs (Table 4). Immobilization of $\mathrm{N}$ by MW compost as reported by Hornick (1988) was not evident in the leaf $\mathrm{N}$ concentration of peppers (Table 3 ), probably because the MW was not soil incorporated.

Leaf $\mathrm{P}, \mathrm{K}$, and $\mathrm{Zn}$ concentrations were higher and $\mathrm{Mg}$ was lower in OM and LM than in PL plots. The lower leaf P concentration in plants from PL plots may be a result of $\mathrm{P}$ use by fruit, which were earlier and larger on plants in PL plots (Table 4). Thomas and Heilman (1964) reported that leaf $P$ concentrations in peppers decreased as fruit developed if adequate $\mathrm{N}$ was present but increased if $\mathrm{N}$ was deficient.

Plants from SY plots were generally larger and higher-yielding than plants from the other OMs (Table 4). This suggests that there may be some dilution of nutrients in foliage and earlier and/or greater translocation of nutrients into fruit of SY plots than on MW or WC. Thomas and Heilman (1964) reported declining leaf $\mathrm{N}$ concentration of bell peppers as fruit neared the green-mature stage, suggesting that $\mathrm{N}$ was translocated from leaves to fruit.

Leaf $\mathrm{Mn}$ and $\mathrm{Cu}$ concentrations were very high in all samples (Table 3), probably because fungicides containing $\mathrm{Mn}$ and $\mathrm{Cu}$ were applied to the plants.

Plant stands. No significant interactions occurred for plant stand (Table 4). At 101 and 107 days after transplanting, stands were lower in PL plots compared with other plots. Phytophthora capsici was detected in root and stem samples taken from several plots. The disease is associated with excess water and is spread by splashing water (Black et al., 1991). Rainfall during January 1993 was $>300 \mathrm{~mm}$, so conditions were ideal for disease development. Madden and Ellis (1990) reported increased splashing of simulated rainfall on PL-mulched strawberries (Fragaria $\times$ ananassa Duch.) compared with those mulched with straw. Elmer and Ferrandino (1991) reported earlier onset of Verticillium dahliae in eggplant (Solanum melongena L.) grown with PL mulch compared with unmulched plants.

Shoot and root growth. Shoots of pepper plants from PL plots were larger than those of plants from other plots (Table 4). Shoot weights were similar among plants from OM or LM plots.

Percentages of root mass in the mulches and at the two soil depths were similar, which may be due to the inherent variability of root systems, the root sampling method (Asghar et al., 1987), or the placement of drip emitters (Bar-Yosef et al., 1980). Coefficients of variation for roots in the mulches and at 0.0 to 7.5 and 7.5 to $15.0 \mathrm{~cm}$ deep were 89,34 , and 48 , respectively.

Transplanting crews, accustomed to working with PL mulch, tended to place the root systems of the plants in the mulches rather than deeper into the soil. This encouraged the growth of roots in the mulches and may have accounted for some of the decreased yields from plants in the WC plots. Inbar et al. (1993) reported that using wood products in potting mixes often results in $\mathrm{N}$ deficiency in plants. The chips we used were large, with pieces as long as $7 \mathrm{~cm}$, making adequate contact between roots and soil difficult.

Fruit yields. The $\mathrm{OM} \times \mathrm{LM}$ interactions were not significant for fruit yields (Table 4). Total yields from PL plots were higher than from LM and OM plots. Yields of bell peppers on PL mulch increased $25 \%$ in a wet year and $3 \%$ in a dry year compared with yields of pepper plants grown with no mulch (Locascio and Fiskell, 1977). Maynard et al. (1962) reported increases in early and total yields of peppers with increasing $\mathrm{N}$ due to higher fruit set. Total fruit yields, yields per plant, and fruit size (Table 4) were generally higher from plants grown in plots with high soil $\mathrm{N}$ and $\mathrm{K}$ concentrations (Table 2). In a tropical environment, pepper plants mulched

Table 3. Nutrient concentration of pepper leaves from plots mulched with polyethylene or organic and living mulches.

\begin{tabular}{|c|c|c|c|c|c|c|c|c|c|}
\hline \multirow[b]{2}{*}{ Mulch $^{y}$} & $\mathrm{~N}^{\mathrm{z}}$ & $\mathrm{P}$ & $\mathrm{K}$ & $\mathrm{Ca}$ & $\mathrm{Mg}$ & $\mathrm{Zn}$ & $\mathrm{Mn}$ & $\mathrm{Cu}$ & $\mathrm{Fe}$ \\
\hline & \multicolumn{5}{|c|}{$(\%)$} & \multicolumn{4}{|c|}{$\left(\mathrm{mg} \cdot \mathrm{kg}^{-1}\right)$} \\
\hline$\overline{\mathrm{PL}}$ & 5.1 & 0.34 & 3.8 & 2.16 & 0.86 & 85.0 & 392 & 304 & 100 \\
\hline \multicolumn{10}{|c|}{ Living mulch (LM) } \\
\hline FT & $5.3 \mathrm{a}^{\mathrm{x}}$ & $0.58 \mathrm{a}$ & 4.4 & 2.06 & 0.54 & 100.1 & $383 \mathrm{~b}$ & $313 \mathrm{~b}$ & 116 \\
\hline $\mathrm{JD}$ & $5.2 \mathrm{a}$ & $0.52 \mathrm{~b}$ & 4.4 & 2.15 & 0.55 & 95.7 & $396 \mathrm{ab}$ & $327 \mathrm{ab}$ & 122 \\
\hline PP & $5.1 \mathrm{ab}$ & $0.52 \mathrm{~b}$ & 4.6 & 2.14 & 0.52 & 98.5 & $420 \mathrm{a}$ & $348 \mathrm{a}$ & 114 \\
\hline SP & $4.9 \mathrm{~b}$ & $0.53 \mathrm{~b}$ & 4.3 & 2.18 & 0.57 & 96.0 & $409 \mathrm{ab}$ & $334 \mathrm{ab}$ & 130 \\
\hline \multicolumn{10}{|c|}{ Organic mulch (OM) } \\
\hline MW & 5.2 & 0.50 & $4.2 \mathrm{c}$ & $2.27 \mathrm{a}$ & 0.54 & $100.8 \mathrm{a}$ & 394 & 324 & 118 \\
\hline WC & 5.1 & 0.57 & $4.5 \mathrm{~b}$ & $1.99 \mathrm{c}$ & 0.55 & $98.9 \mathrm{a}$ & 423 & 340 & 132 \\
\hline SY & 5.1 & 0.54 & $4.6 \mathrm{a}$ & $2.13 \mathrm{~b}$ & 0.54 & $93.1 \mathrm{~b}$ & 389 & 328 & 111 \\
\hline \multicolumn{10}{|l|}{ Interaction } \\
\hline $\mathrm{OM} \times \mathrm{LM}$ & NS & NS & $*$ & NS & $*$ & NS & NS & NS & NS \\
\hline \multicolumn{10}{|l|}{ Contrasts } \\
\hline PL vs. others & NS & $* *$ & $* *$ & NS & $* *$ & $* *$ & NS & NS & NS \\
\hline
\end{tabular}

zTotal Kjeldahl N.

' $\mathrm{PL}=$ polyethylene, $\mathrm{FT}$ = 'Floratam', JD = 'Jade', $\mathrm{PP}=$ perennial peanut, $\mathrm{SP}$ = seed-propagated forage peanut, $\mathrm{MW}=$ municipal solid waste compost, $\mathrm{WC}=$ wood chips, $\mathrm{SY}=$ sewage sludge-yard trimming compost.

xMean separation in columns within mulch types by Duncan's multiple range test, $P=0.05$.

Ns,**** Nonsignificant or significant at $P=0.05$ or 0.01 , respectively. 
Table 4. Bell pepper plant stands, shoot weight, root weights from soil cores, and yields from plots mulched with white polyethylene or organic materials.

\begin{tabular}{|c|c|c|c|c|c|c|c|c|c|c|}
\hline \multirow[b]{3}{*}{$\operatorname{Mulch}^{\mathrm{x}}$} & \multirow{2}{*}{\multicolumn{2}{|c|}{$\frac{\text { Stand }(\%)}{\text { DAT }^{\mathrm{z}}}$}} & \multirow{3}{*}{$\begin{array}{l}\text { Shoot } \\
\text { wt (g) }\end{array}$} & \multicolumn{3}{|c|}{ Root $(\%)$} & \multicolumn{4}{|c|}{ Fruit yield } \\
\hline & & & & \multirow[b]{2}{*}{ Mulch } & \multicolumn{2}{|c|}{ Soil depth $(\mathrm{cm})$} & \multirow[b]{2}{*}{$\left(\mathrm{t} \cdot h \mathrm{~h}^{-1 \mathrm{w}}\right)$} & \multirow[b]{2}{*}{$\left(\mathrm{g} /\right.$ plant $\left.^{\mathrm{w}}\right)$} & \multirow{2}{*}{$\begin{array}{c}\text { Early }^{\mathrm{y}} \\
(\%)\end{array}$} & \multirow{2}{*}{$\begin{array}{c}\text { Size } \\
\text { (g/fruit) }\end{array}$} \\
\hline & 101 & 107 & & & $0-7.5$ & $7.5-15$ & & & & \\
\hline $\mathrm{PL}$ & 18 & 2 & 28.1 & 0 & 52.0 & 48.0 & 6.99 & 329 & 98 & 206 \\
\hline \multicolumn{11}{|c|}{ Living mulch (LM) } \\
\hline FT & 73 & 54 & 10.2 & 12.5 & 57.8 & 29.7 & 2.86 & 116 & $62 b^{v}$ & 174 \\
\hline $\mathrm{JD}$ & 72 & 50 & 11.0 & 18.9 & 49.1 & 32.0 & 3.23 & 136 & $67 \mathrm{ab}$ & 179 \\
\hline PP & 63 & 45 & 11.2 & 24.1 & 51.7 & 24.2 & 2.51 & 114 & $69 a b$ & 182 \\
\hline SP & 62 & 40 & 12.1 & 6.0 & 56.3 & 37.7 & 3.18 & 142 & $78 \mathrm{a}$ & 189 \\
\hline \multicolumn{11}{|c|}{ Organic mulch $(\mathrm{OM})$} \\
\hline MW & 71 & 51 & 11.3 & 10.9 & 57.6 & 31.5 & $2.95 \mathrm{~b}$ & $122 \mathrm{~b}$ & $70 \mathrm{ab}$ & 174 \\
\hline WC & 62 & 43 & 8.8 & 13.4 & 46.9 & 39.7 & $1.86 \mathrm{c}$ & $86 \mathrm{~b}$ & $59 \mathrm{~b}$ & 192 \\
\hline SY & 70 & 49 & 13.4 & 21.9 & 56.7 & 21.4 & $4.03 \mathrm{a}$ & $174 \mathrm{a}$ & $77 \mathrm{a}$ & 176 \\
\hline \multicolumn{11}{|l|}{ Interaction } \\
\hline $\mathrm{OM} \times \mathrm{LM}$ & NS & NS & NS & NS & NS & NS & NS & NS & NS & NS \\
\hline \multicolumn{11}{|l|}{ Contrasts } \\
\hline PL vs. others & $* *$ & $* *$ & $* *$ & --- & NS & NS & $* *$ & $* *$ & $* *$ & $* *$ \\
\hline
\end{tabular}

${ }^{\mathrm{Z}} \mathrm{DAT}=$ days after transplanting.

yPercentage of fruit in first harvest.

${ }^{x} \mathrm{PL}=$ polyethylene, $\mathrm{FT}=$ 'Floratam', JD = 'Jade', $\mathrm{PP}=$ perennial peanut, $\mathrm{SP}$ = seed-propagated forage peanut, $\mathrm{MW}=$ municipal solid waste compost,

$\mathrm{WC}=$ wood chips, $\mathrm{SY}=$ sewage sludge-yard trimming compost.

wTotal of two harvests: 28 Dec. 1992 and 15 Jan. 1993.

'Mean separation in columns within mulch types by Duncan's multiple range test, $P=0.05$.

Ns, ${ }^{* *}$ Nonsignificant or significant at $P=0.01$.

with organic materials produced lower yields than plants mulched with white, silver, or black PL or unmulched plants in summer or winter (Goyal et al., 1984).

Smaller plants and decreased yields in OM, especially in WC plots (Table 4), suggest a lack of N. Plants in WC plots were also lighter in color than others (data not shown). Soil tests indicated lower $\mathrm{NO}_{3}$ in $\mathrm{OM}$ plots (Table 2), so a dilution effect may have accounted for the similar leaf tissue results. This apparent decrease in available $\mathrm{N}$ in $\mathrm{OM}$ plots may be due to a combination of leaching, immobilization, and volatilization. Locascio and Fiskell (1977) suggested that higher soil N content measured under PL mulch plots compared with unmulched soil was due to decreased leaching under PL. The immobilization of $\mathrm{N}$ by compost has been reported (Jimenez and Garcia, 1989). Although some composts contain large amounts of $\mathrm{N}$, mineralization often proceeds slowly and the $\mathrm{N}$ may not be available at the critical time for plant uptake. In several trials with mushroom (Agaricus spp.) compost, tomato yields increased only when the compost was supplemented with $\mathrm{N}$, P, and K (Stephens et al., 1989).

Early yields from PL plants accounted for $98 \%$ of the harvest, as only $2 \%$ of the plants were still living by the second harvest date (Table 4). Percentage of early yields from plants in WC plots was lower than from plants in SY plots. This reflected the inhibited growth of plants in WC plots.

\section{Winter squash experiment}

Soil temperatures. Although morning temperatures were similar, midday and evening temperatures under PL were higher than in OM and LM plots (Table 5). Midday temperatures in OM plots were highest under MW and lowest under WC, probably due to differences in color and insulating properties of the mulches.

Plots with peanut LMs had higher evening temperatures than grass-mulched plots. The grass covered bed sides more uniformly and heavily than the peanuts (data not shown), thereby protecting the soil from direct radiation.
Plant stands. Although final stands were similar (Table 5), earlier emergence of squash seedlings was noted in OM plots, probably because nighttime temperatures under these mulches remained warmer than under PL during the germination period (data not shown). More favorable growing conditions resulted in fewer disease losses of the squash crop during the season than of the pepper crop.

Plant stands of MW plots were the highest of any of the OMs (Table 5). Direct seeding in OM usually resulted in placing seed directly in the mulch. Germination percentages of radish (Raphanus sativus L.), dill (Anethum graveolens L.), and alfalfa (Medicago sativa $\mathrm{L}$.) have been lower in SY than MW compost (Roe and Kostewicz, 1992). Placing seed directly in the WC mulch may have inhibited germination in that mulch. Plant stand in PP plots was lower than that in the other LMs, probably because vigorous growth of PP through the beds resulted in a competitive effect.

Fruit yield. Total fruit yields were similar among treatments (Table 5). Number of fruit per plant (34) from PL-mulched plots was higher compared with fruit per plant (24) from OM plots, resulting in smaller fruit from plants in PL plots. Schales and Sheldrake (1966) reported no significant differences in muskmelon yields from plants mulched with clear or white PL compared with plants mulched with peatmoss. When straw mulch was compared with clear, white, or black PL mulch another year, muskmelon yields were higher in all PL mulches (Schales and Sheldrake, 1966).

Improved crop growth with OMs or composts has been attributed to reduced weed growth (Carter and Johnson, 1988), temperature moderation (Palada al. 1992), retained soil moisture (Asghar et al., 1987), changes in soil physical condition (Batista y Cuba, 1943), and suppression of plant pathogens (Bryan and Lance, 1991). Despite reduced plant stands in PL-mulched plots, pepper plants were larger and produced higher yields than those grown with OMs. However, in the subsequent squash crop, these yield differences were not evident. The economics of PL vs. compost 
Table 5. Soil temperatures, squash plant stands, and yields from plots mulched with white polyethylene or organic and living mulches.

\begin{tabular}{|c|c|c|c|c|c|c|c|}
\hline \multirow[b]{2}{*}{ Mulch $^{y}$} & \multicolumn{3}{|c|}{ Soil temp $\left({ }^{\circ} \mathrm{C}\right)^{\mathrm{z}}$} & \multirow{2}{*}{$\begin{array}{l}\text { Stand }(\%) \\
28 \mathrm{DAS}^{\mathrm{x}}\end{array}$} & \multicolumn{2}{|c|}{ Fruit yield } & \multirow{2}{*}{$\begin{array}{c}\text { Fruit size } \\
\text { (g/fruit) }\end{array}$} \\
\hline & Morning & Midday & Evening & & $\left(\mathrm{t} \cdot \mathrm{ha}^{-1}\right)$ & (g/plant) & \\
\hline PL & 17.0 & 23.1 & 23.6 & 62 & 9.51 & 973 & 436 \\
\hline \multicolumn{8}{|c|}{ Living mulch (LM) } \\
\hline $\mathrm{FT}$ & 17.6 & 21.5 & $22.2 b^{w}$ & $56 \mathrm{a}$ & 8.95 & 871 a & 556 \\
\hline $\mathrm{JD}$ & 17.4 & 21.6 & $22.5 \mathrm{ab}$ & $56 \mathrm{a}$ & 9.56 & $943 \mathrm{a}$ & 535 \\
\hline PP & 17.5 & 21.5 & $22.6 \mathrm{a}$ & $47 \mathrm{~b}$ & 7.79 & 869 a & 574 \\
\hline SP & 16.9 & 21.5 & $22.7 \mathrm{a}$ & $59 \mathrm{a}$ & 7.19 & $698 \mathrm{~b}$ & 537 \\
\hline \multicolumn{8}{|c|}{ Organic mulch (OM) } \\
\hline MW & 17.4 & $21.7 \mathrm{a}$ & 22.5 & $60 \mathrm{a}$ & 8.18 & $768 \mathrm{~b}$ & 541 \\
\hline WC & 17.5 & $21.4 \mathrm{~b}$ & 22.4 & $50 \mathrm{~b}$ & 7.87 & $819 \mathrm{ab}$ & 554 \\
\hline SY & 17.2 & $21.6 \mathrm{ab}$ & 22.6 & $54 \mathrm{~b}$ & 9.07 & $948 \mathrm{a}$ & 557 \\
\hline \multicolumn{8}{|l|}{ Interaction } \\
\hline $\mathrm{OM} \times \mathrm{LM}$ & NS & NS & NS & NS & NS & NS & NS \\
\hline \multicolumn{8}{|l|}{ Contrasts } \\
\hline PL vs. others & NS & $* *$ & $* *$ & NS & NS & NS & $* *$ \\
\hline
\end{tabular}

${ }^{\bar{z}}$ Temperatures recorded at $15 \mathrm{~cm}$ soil depth for 8 days in March 1993.

yPL = polyethylene, FT = 'Floratam', JD = 'Jade', $\mathrm{PP}=$ perennial peanut, $\mathrm{SP}=$ seed-propagated forage peanut, $\mathrm{MW}=$ municipal solid waste compost, $\mathrm{WC}=$ wood chips, $\mathrm{SY}=$ sewage sludge-yard trimming compost.

${ }^{x}$ Days after seeding.

${ }^{w}$ Mean separation in columns within mulch types by Duncan's multiple range test, $P=0.01$.

ss, ${ }^{* *}$ Nonsignificant or significant at $P=0.01$.

mulches, practical application methods, and long-term effects of compost use in vegetable crop production systems also warrant evaluation.

\section{Literature Cited}

Asghar, M., D. Bounie, and M. Prasad. 1987. Effects of mulch and fertilizer on soil moisture, and corn (Zea mays L.) growth and root proliferation. Alafua Agr. Bul. 12:31-41.

Bar-Yosef, B., C. Stammers, and B. Sagiv. 1980. Growth of trickleirrigated tomato as related to rooting volume and uptake of $\mathrm{N}$ and water. Agron. J. 72:815-822.

Batista y Cuba, J.W. 1943. The effect of mulch and chemical treatments on microbiological action in soils. MS thesis. Univ. of Florida, Gainesville.

Black, L.L., S.K. Green, G.L. Hartman, and J.M. Poulos. 1991. Pepper diseases, a field guide. Asian Veg. Res. Dev. Center, Tapei.

Bryan, H.H. and C.J. Lance. 1991. Compost trials on vegetables and tropical crops. Biocycle 27(3):36-37.

Carter, J. and C. Johnson. 1988. Influence of different types of mulches on eggplant production. HortScience 23:143-145.

Duxbury, J.M., M.S. Smith, and J.W. Doran. 1989. Soil organic matter as a source and a sink of plant nutrients, p. 33-67. In: D.C. Coleman, J.M. Dads, and G. Uehara (eds.). Dynamics of soil organic matter in tropical ecosystems. Niftal Project, Honolulu.

Elmer, W.H. and F.J. Ferrandino. 1991. Effect of black plastic mulch and nitrogen side-dressing on verticillium wilt of eggplant. Plant Dis. 75(11):1164-1167.

Goyal, M.R., R. Guadalupe-Luna, L.E. Rivera, and E.R. deHernandez. 1984. Effects of plastic mulch types on crop performance of drip irrigated winter and summer peppers. J. Agr. Univ. Puerto Rico. 68(3):297-300.

Grubinger, V.P. and P.L. Minotti. 1990. Managing white clover living mulch for sweet corn production with partial rototilling. Amer. J. Alternative Agr. 5(1):4-12.

Hanlon, E.A. and J.M. DeVore. 1989. IFAS extension soil testing laboratory chemical procedures and training manual. Florida Coop. Ext. Circ. 812.

Hanlon, E.A., G. Kidder, and B.L. McNeal. 1990. Soil, container media, and water testing-Interpretations and IFAS standardized fertilization recommendation. Florida Coop. Ext. Circ. 817.

Harada, Y. and A. Inoko. 1975. Cation-exchange properties of soil organic matter. I. Effects of conditions for the measurement on cation-exchange capacity values of humic acid preparations. Soil Sci. Plant Nutr. 21(4):361-369.

Hinton, A.C. and P.L. Minotti. 1983. Differential response of grass species to fluazifop and sethoxydim. Proc. Annu. Mtg. N.E. Weed Sci. Soc. 37:161-162.

Hochmuth, G.J. 1988. Pepper production guide for Florida. Univ. of Fla. Coop. Ext. Serv. Circ. 102E.

Hochmuth, G., D. Maynard, C. Vavrina, and E. Hanlon. 1991. Plant tissue analysis and interpretation for vegetable crops in Florida. Univ. of Florida Bul. SS-VEC-42.

Hornick, S.B. 1988. Use of organic amendments to increase the productivity of sand and gravel spoils: Effect on yield and composition of sweet corn. Amer. J. Alternative Agr. 3(4):156-162.

Inbar, Y., Y. Chen, and H.A.J. Hoitink. 1993. Properties for establishing standards for utilization of composts in container media, p. 668-694. In: H.A.J. Hoitink and H.M. Keener (eds.). Science and engineering of composting: Design, environmental, microbiological and utilization aspects. Renaissance Publ., Worthington, Ohio.

Jackson, L.E. and A.J. Bloom. 1990. Root distribution in relation to soil nitrogen availability in field-grown tomatoes. Plant and Soil 128:115126.

Jimenez, E.I. and V.P. Garcia. 1989. Evaluation of city refuse compost maturity: A review. Biol. Wastes 27:115-142.

Jimenez, E.I. and V.P. Garcia. 1992. Determination of maturity indices for city refuse composts. Agr. Ecosystems Environ. 38:331-343.

Locascio, S.J. and J.G.A. Fiskell. 1977. Pepper production as influenced by mulch, fertilizer placement, and nitrogen rate. Proc. Soil Crop Soc. of Florida 36:113-117.

Madden, L.V. and M.A. Ellis. 1990. Effect of ground cover on splash dispersal of Phytophthora cactorum from strawberry fruits. J. Phytopathol. 129:170-174.

Maynard, D.N., W.H. Lachman, R.M. Check, and H.F. Vernell. 1962. The influence of nitrogen levels on flowering and fruit set of peppers. Proc. Amer. Soc. Hort. Sci. 81:385-389.

Miller, C.H. 1960. Some effects of different levels of five nutrient elements on bell peppers. Proc. Amer. Soc. Hort. Sci. 77:440-448.

Nelson, D.W. and L.E. Sommers. 1982. Total carbon, organic carbon, and organic matter, p. 539-579. In: A.L. Page, R.H. Miller, and D.R. Keeney (eds.). Methods of soil analysis. part 2. Chemical and microbiological properties. 2nd ed. Amer. Soc. Agron., Soil Sci. Soc. Amer. Madison, Wis.

O’Keefe, B.E., J. Axley, and J.J. Meisinger. 1986. Evaluation of nitrogen 
availability indexes for a sludge compost amended soil. J. Environ. Quality 15(2):121-128.

Palada, M.C., S.M.A. Crossman, and C.D. Collingwood. 1992. Effect of organic and synthetic mulches on yield of basil under drip irrigation. HortScience 27:99. (Abstr.)

Paul, E.A. and F.E. Clark. 1989. Soil microbiology and biochemistry. Academic Press, San Diego.

Roe, N.E. and S.R. Kostewicz. 1992. Germination and early growth of vegetable seed in composts. Natl. Symp. Stand Establishment Hort. Crops. Univ. Fla. Proc. 101:191-201.

Schales, F.D. and R. Sheldrake, Jr. 1966. Mulch effects on soil conditions and muskmelon response. Proc. Amer. Soc. Hort. Sci. 88:425-430.
Servis, R. 1992. Ag plastic recycling on horizon. Florida Grower Rancher 85:40.

Stephens, J.M., G.C. Henry, B.F. Castro, and D.L. Bennett. 1989. Mushroom compost as a soil amendment for vegetable gardens. Proc. Florida State Hort. Soc. 102:108-111.

Thomas, J.R. and M.D. Heilman. 1964. Nitrogen and phosphorus content of leaf tissue in relation to sweet pepper yields. Proc. Amer. Soc. Hort. Sci. 85:419-425.

Tukey, R.B. and E.L. Schoff. 1963. Influence of different mulching materials upon the soil environment. Proc. Amer. Soc. Hort. Sci. 82:68-76.

Wolfe, B. 1982. An improved universal extracting solution. and its use for diagnosing soil fertility. Commun. Soil Sci. Plant Anal. 13:1005-1033. 